\title{
KOMODIFIKASI PERBEDAAN DALAM MASYARAKAT DIGITAL (TINJAUAN SOSIOLOGI TERHADAP KOMODITAS KAPITALISME DI ERA MASYARAKAT DIGITAL)
}

\author{
Nistiarisa Angelina ${ }^{1}$
}

\begin{abstract}
Abstrak
Globalisasi yang ditandai dengan perkembangan teknologi dan komunikasi menjadikan tumbuh suburnya industri telekomunikasi. Artikel ini menarik hubungan lebih luas ke dalam dimensi globalisasi yang melibatkan hubungan antar negara dalam kerangka struktur sistem ekonomi kapitalis dunia untuk menganalisis masyarakat digital di Indonesia, serta dampaknya dalam aspek ekonomi, sosial dan politik. Indonesia sebagai negara berkembang dengan jumlah penduduk terbanyak di dunia serta didukung tingkat perekonomian yang mengalami kenaikan setiap tahunnya menjadi target pasar strategis industri telekomunikasi. Penetrasi teknologi telekomunikasi menempatkan Indonesia menduduki peringkat dunia sebagai masyarakat dengan tingkat konsumsi terbesar dalam penggunaan internet, ponsel, hingga jejaring sosial media. Bentuk dan pola komunikasi bergeser menciptakan era masyarakat digital yang merupakan dampak dari dualitas masyarakat dan struktur ekonomi kapitalis melahirkan sikap penerimaan masyarakat dalam konsep masyarakat konsumsi pasif dan potensial. Implikasinya hubungan eksploitatif terjadi pada masyarakat konsumsi potensial terhadap masyarakat konsumsi pasif melalui komodifikasi perbedaan di ranah komunikasi media sosial. Perbedaan sebagai isu masyarakat multikulktural dinarasikan dalam bentuk agitasi untuk mendukung kepentingan. Upaya membangun kesadaran melalui pendidikan diajukan untuk melindungi dari potensi konflik destruktif yang mengakibatkan instabilitas bangsa.
\end{abstract}

Kata Kunci: kapitalisme, komodifikasi, masyarakat digital, masyarakat konsumsi, multikultural

\footnotetext{
${ }^{1}$ Mahasiswa Pascasarjana, Universitas Gadjah Mada, Indonesia
} 


\section{PENDAHULUAN}

Hadirnya globalisasi yang ditandai semakin pesatnya perkembangan teknologi dan komunikasi menjadikan sumber informasi semakin mudah dijangkau oleh masyarakat. Akses informasi yang semakin mudah dijangkau didukung oleh lahirnya industri telekomunikasi. Semula akses informasi didapatkan melalui media cetak dan elektronik, namun seiring perkembangan teknologi dan komunikasi media sosial mulai mengambil alih peran tersebut. Pertukaran informasi dan komunikasi menjadi semakin intens. Interaksi menjadi tidak mengenal batas.

Di Indonesia, perkembangan perkembangan teknologi dan komunikasi turut mempengaruhi kehidupan multikultural masyarakat dalam aspek ekonomi, sosial dan politik. Dampak perkembangan teknologi dan komunikasi lebih banyak dilihat dari kacamata sosial yaitu perubahan pola perilaku masyarakat. Sebuah penelitian tentang dampak perkembangan perkembangan teknologi dan komunikasi terhadap eksistensi budaya lokal menunjukkan hasil budaya dari setiap negara akan melebur menjadi satu yaitu budaya global dengan poros utama adalah budaya dari negara maju sehingga menjadi acuan bagi negara lain yang pada akhirnya akan menjadi ancaman utama bagi budaya lokal (Nasution, 2017).

Dalam hal ini, aspek ekonomi dan politik seringkali diabaikan. Padahal dampak perkembangan perkembangan teknologi dan komunikasi dalam aspek ekonomi dan politik harus lebih diwaspadai karena berpotensi mengancam integrasi bangsa. Kasus terbongkarnya jaringan Saracen yang menjadi bahan perbincangan masyarakat dan headline news di berbagai media menunjukkan bahwa aspek ekonomi, sosial dan politik tidak dapat dipisahkan dalam analisis mengenai masyarakat digital.

Di negara berkembang, seperti halnya Indonesia, globalisasi hadir menjadi perdebatan yang ditanggapi optimis namun juga pesimis. Di satu sisi globalisasi diharapkan dapat memperluas pasar serta mempercepat gerak modal, barang dan uang. Namun disisi lain globalisasi juga dianggap hanya menguntungkan pihak-pihak tertentu yang telah siap, sisanya hanya menghadirkan penguasaan dan ketergantungan. Analisis terbentuknya masyarakat digital di Indonesia akibat adanya globalisasi yang ditandai dengan semakin berkembangnya teknologi dan komunikasi harus ditarik dalam kerangka dimensi globalisasi yang lebih luas dalam sistem ekonomi kapitalis dunia (Giddens, Konsekuensi-Konsekuensi Modernitas, 2005). Selanjutnya, analisis dampak masyarakat digital di Indonesia juga harus dinilai dari ketiga aspek yaitu ekonomi, sosial dan politik. Berkaca pada kasus Saracen yang viral, multikulturalisme di Indonesia dengan banyaknya perbedaan sangat rentan akan adanya konflik yang berpotensi mengancam integrasi bangsa. 
Dualitas antara struktur dan agensi menjadi hal yang tidak dapat dipisahkan, dimana struktur mengarahkan agensi layaknya pedoman, prinsip dan aturan dalam proses perulangan tindakan sosial melalui penandaan atau signifikasi, dominasi atau penguasaan dan pembenaran atau legitimasi (Giddens, Teori Strukturasi: Dasar-Dasar Pembentukan Struktur Sosial Masyarakat, 2010). Analisis mengenai kerentanan masyarakat digital multikultural di Indonesia pertama harus dilihat dari pembentuknya, proses, dampak dan potensi yang dapat dikembangkan untuk meminimalisasi dampak. Konsep kesadaran dari diskursif, kesadaran praktis, dan motifmotif tidak sadar/kognisi dapat menjadi jalan keluar dari permasalahan kerentanan masyarakat digital multikultural di Indonesia (Giddens, Teori Strukturasi: Dasar-Dasar Pembentukan Struktur Sosial Masyarakat, 2010).

\section{METODOLOGI}

Artikel ini menggunakan pendekatan deskriptif kualitatif dengan metode penelitian kepustakaan untuk mendiskripsikan proses dan dampak dimensi globalisasi di Indonesia sebagai negara multikultural dengan banyak perbedaan di dalamnya. Sumber data yang digunakan diperoleh berdasarkan sumber acuan umum yaitu buku teori dan sumber acuan khusus yaitu jurnal hasil penelitian, hasil survei, berita dan observasi terhadap aktivitas dan perilaku warganet Indonesia pada media sosial instagram (Harahap, 2014).

Metode pengumpulan data yang digunakan dalam penelitian ini adalah studi pustaka pada sumber data teks dan observasi terhadap aktivitas dan perilaku warganet Indonesia pada media sosial instagram. Triangulasi sumber data dilakukan melalui pemilihan sumber data yang kredibel. Metode analisis data yang digunakan adalah analisis isi atau metode melalui analisis dokumen yaitu dengan pengujian teoritis untuk meningkatkan pemahaman tentang data untuk menyaring informasi ke dalam kategori terkait (Elo \& Kyngas, 2008). Teori digunakan sebagai kerangka berpikir dalam menganalisis kerentanan masyarakat digital multikultural di Indonesia mulai dari pembentuknya, proses, dampak dan potensi yang dapat dikembangkan untuk meminimalisasi dampak perkembangan teknologi dan komunikasi. Selanjutnya menarik kesimpulan akhir berdasarkan data yang telah ditampilkan.

\section{HASIL}

Globalisasi yang ditandai dengan perkembangan teknologi dan komunikasi menjadikan tumbuh suburnya industri telekomunikasi. Di Indonesia perkembangan teknologi dan komunikasi, terutama sejak pergantian dari telepon genggam ke smartphone membuka semakin banyak 
kompetisi persaingan pasar, mulai dari provider, smartphone hingga aplikasi. Dilansir dari laman e-commerce https://www.jd.id/ pada Oktober 2017, tercatat sebanyak 23 merk smartphone yang dapat dibeli online secara bebas di Indonesia. Namun, dari sekian banyak merk yang beredar di pasar sebagian besar bukanlah produksi Indonesia, hanya ada beberapa yang asli buatan Indonesia. Klaim asli buatan Indonesia pun juga masih membuka dua kemungkinan, yaitu dibuat di Indonesia namun bukan milik Indonesia atau milik Indonesia namun komponen hardware masih menggunakan produk asing. Misalnya smartphone Tiongkok made in Indonesia yang pada akhir 2014 telah mendirikan pabrik untuk produksi smartphone secara lokal (Perdana, 2017).

Indonesia sebagai negara berkembang dengan jumlah penduduk terbanyak di dunia serta didukung tingkat perekonomian yang mengalami kenaikan setiap tahunnya menjadi target pasar strategis industri telekomunikasi. Market share untuk penjualan produk smartphone semakin meningkat dan didominasi oleh perusahaan asing. Perusahaan produksi smartphone Korea Selatan masih merajai pasar penjualan di Indonesia dengan market share 32,2\% untuk kuartal ketiga tahun 2016, yang mana persentase tersebut naik signifikan dari 26 persen pada kuartal sebelumnya (Bohang, Samsung Masih Rajai Pasar Smartphone Indonesia, Ditempel
Oppo, 2016). Padahal penggunaan smartphone juga membutuhkan dukungan konsumsi di bidang lain mulai dari provider penyedia layanan untuk pulsa telepon, SMS dan jaringan internet untuk akses aplikasi dan media sosial.

Penetrasi teknologi telekomunikasi menempatkan Indonesia menduduki peringkat dunia sebagai masyarakat dengan tingkat konsumsi terbesar dalam penggunaan internet, ponsel, hingga jejaring media sosial. Berdasarkan data Hasil Susenas BPS Maret 2016 konsumsi rata-rata pulsa mencapai Rp22.182 per kapita per bulan mengalahkan konsumsi rata-rata buah Rp19.268 dan daging Rp20.526 per kapita per bulan (Badan Pusat Statistik, 2016). Indonesia sendiri berdasarkan data Internet World Statistics berada pada rangking lima penggunaan internet terbesar di dunia dari Top 20 Internet Countries (Faliyandra, 2017). Indonesia juga menduduki ranking kelima dunia sebagai pengguna twitter (Sukoco, 2017). Ini belum termasuk ranking dalam hal pengguna instagram terbesar seAsia Pasifik dengan pengguna aktif bulanan atau monthly active user (MAU) yang meningkat lebi dari $200 \%$ dari tahun sebelumnya (Bohang, Indonesia, Pengguna Instagram Terbesar se-Asia Pasifik, 2017).

Analisis artikel ini menarik hubungan lebih luas ke dalam dimensi globalisasi yang melibatkan hubungan antar negara dalam kerangka struktur sistem ekonomi kapitalis dunia untuk menganalisis masyarakat digital 
di Indonesia. Bentuk dan pola komunikasi bergeser menciptakan era masyarakat digital yang merupakan dampak dari dualitas masyarakat dan struktur ekonomi kapitalis. Sistem ekonomi kapitalis dunia sengaja menciptakan kebutuhan semu bagi target konsumen untuk mencapai tujuan memperoleh keuntungan sebanyak-banyaknya. Masyarakat Indonesia dalam hal ini adalah target eksploitasi dari negara-negara produsen produk telekomunikasi.

Menganalisis strukturasi berarti menjelaskan bagaimana aktivitas masyarakat sebagai agen dalam konteks tindakan tertentu tidak lepas dari struktur dalam tata sistem ekonomi kapitalis, narasi akan perbedaan antara konsep modern berbasis teknologi dan tradisional yang kuno merupakan bentuk struktur penandaan atau signifikasi (Giddens, Teori Strukturasi: Dasar-Dasar Pembentukan Struktur Sosial Masyarakat, 2010). Perbedaan gaya hidup yaitu dualisme modern dan tradisional menjadi komoditi untuk diperdagangkan dan terbukti meraih kesuksesan. Maka untuk mencapai modernitasnya negara berkembang seolah harus mengikuti negara maju. Kepemilikan akan produk telekomunikasi berubah bentuk menjadi simbol kesejahteraan. Maka esensi menjadi tertutup oleh eksistensi. Pasar produk asing dapat menguasai Indonesia bukan tanpa sengaja, melainkan dengan strategi dan riset market yang telah terencana.
Liberalisasi yang mengakibatkan terbukanya akses impor dan penciptaan kebutuhan semu secara terus-menurus untuk memperluas ekspansi ekspor negara lain di Indonesia merupakan bentuk struktur dominasi dalam pengertian ekonomi dan politik. Dimensi globalisasi yang dilupakan dalam artikel di atas adalah sistem ekonomi kapitalis dunia yang menghadirkan pasar sebagai aktor dan negara (khususnya negara berkembang, dalam bahasan ini Indonesia) sebagai institusi untuk melegalkan kepentingan ekspansi pasar melalui kebijakankebijakan yang dibuat, serta masyarakat sebagai target eksploitasi (Giddens, Konsekuensi-Konsekuensi Modernitas, 2005). Keputusan keterlibatan dalam sistem perdagangan dunia oleh pemerintah merupakan praktik struktur pembenaran atau legitimasi. Hingga saat ini belum ada kebijakan yang membatasi perihal perangkat telekomunikasi, mulai dari produksi, masuknya pasar asing hingga penggunaan. Perusahaan asing dapat leluasa untuk memasarkan bahkan mendirikan pabrik di Indonesia yang semakin menjadikan kuatnya pengaruh dan besarnya ketergantungan bangsa akan pasar asing. Pernyataan tentang apa yang terjadi di masyarakat serta bagaimana tindakan masyarakat yang terus diproduksi secara terus menerus yang tidak lepas dari strukturasi. Kemampuan introspeksi dan mawas diri dari masyarakat perlu dibangun dari dalam sebagai 
pembentuk aktivitas yang dilakukan (Giddens, Teori Strukturasi: Dasar-Dasar Pembentukan Struktur Sosial Masyarakat, 2010).

\section{DISKUSI}

Upaya menciptakan kebutuhan semu untuk mencapai tujuan memperoleh keuntungan sebanyak-banyaknya dalam sistem ekonomi kapitalis merubah aspek ekonomi, sosial dan politik bagi masyarakat Indonesia. Kasus jaringan Saracen menjadi bukti perkembangan teknologi dan komunikasi dapat berdampak luas pada tiap aspek ekonomi, sosial dan politik yang tidak dapat dipisahkan dalam analisis mengenai masyarakat digital.

Bentuk dan pola komunikasi bergeser menciptakan era masyarakat digital yang merupakan dampak dari dualitas masyarakat dan struktur ekonomi kapitalis melahirkan sikap penerimaan masyarakat dalam konsep masyarakat konsumsi pasif sebagai konsumen sejati dan masyarakat konsumsi potensial yang bertindak sebagai konsumen produk teknologi namun juga dapat memanfaatkan teknologi tersebut. Namun selama ini, penggunaan teknologi komunikasi tidak pernah diimbangi dengan pendidikan mengenai bijak dalam penggunaan. Akibatnya masyarakat konsumsi pasif semakin terjebak dalam motif-motif tidak sadar/kognisi dalam tindakannya atau hanya sebatas kesadaran praktis tanpa dapat merefleksikan tindakan pada resiko yang dicapai dan akibatnya secara luas.
Implikasinya hubungan eksploitatif terjadi pada masyarakat konsumsi potensial terhadap masyarakat konsumsi pasif melalui komodifikasi perbedaan di ranah komunikasi media sosial. Perbedaan sebagai isu masyarakat multikulktural dinarasikan dalam bentuk agitasi untuk mendukung kepentingan. Agitasi publik melalui ujaran kebencian dan hoax dewasa ini semakin berkembang. Pemerintah berupaya keras meredam dengan berbagai tindakan. Pidato presiden hampir selalu menyelipkan himbauan untuk menghentikan tindakan penyebaran ujaran kebencian dan hoax, salah satunya Pidato Jokowi pada Hari Lahir Pancasila yang menyinggung mengenai penyalahgunaan media sosial dan komitmen pemerintah melakukan tindakan tegas (Kuwado, Ini Isi Pidato Jokowi pada Hari Lahir Pancasila yang Disebar ke Penjuru Indonesia, 2017). Tidak berselang lama, kasus Saracen teruangkap. Kasus ini mengungkap fakta bahwa ujaran kebencian dan hoax yang viral di masyarakat sejatinya adalah bisnis yang menjual narasi untuk kepentingan tertentu.

Tidak hanya dalam aspek politik, narasi komodifikasi perbedaan dalam upaya untuk mendapatkan keuntungan juga dilakukan oleh masyarakat konsumsi potensial terhadap masyarakat konsumsi pasif. Viral berbagai akun di instagram yang menampilkan kehidupan aktor yang dianggap menyimpang untuk kemudian dipertontonkan kepada masyarakat. Komodifikasi perbedaan 
dinarasikan untuk kontroversi menarik perhatian publik untuk mendapatkan keuntungan finansial melalui banyaknya pegikut dan iklan pada akun media sosial tersebut. Perbedaan dalam hal ini tidak hanya sebatas suku, bahasa maupun agama, namun juga berkenaan dengan cara berpikir dan bertindak. Hal yang dianggap tidak disesuai dengan nilai dan norma yang dianut masyarakat luas menjadikan kontroversi yang juga mengancam integrasi bangsa walaupun di level kontradiksi dan konfrontasi.

Pernyataan tentang Indonesia sebagai kesatuan wilayah yang tebentang dari Sabang sampai Merauke dengan keragaman suku bangsa, agama dan budaya memang tak terbantahkan. Cerita sejarah kejayaan Nusantara dan semboyan "Bhinneka Tunggal Ika" turut mempertegas bahwa Indonesia adalah satu dari begitu banyak perbedaan. Meski demikian, mewujudkan cita-cita integrasi nasional di tengah begitu banyak perbedaan tidaklah mudah. Kontradiksi menjadi konsekuensi dalam komitmen kehidupan berbangsa dan bernegara. Perubahan pergeseran komunikasi menjadi ancaman ketika mulai ditunggangi oleh kepentingan tertentu. Ujaran kebencian dan hoax dijadikan viral untuk menarik perhatian dan dukungan massa. Isu SARA dimunculkan untuk memupuk primordialisme kubu pro dan kontra.

\section{Globalisasi datang menjadikan}

pertukaran informasi dan komunikasi menjadi semakin intens. Interaksi menjadi tidak mengenal batas. Bukan lagi sekedar isu otonom, kontradiksi dan konfrontasi semakin mudah berkembang menjadi permasalahan nasional. Penyebaran informasi secara meluas mengakibatkan kontradiksi dan konfrontasi tidak berbatas wilayah. Isu di suatu daerah akan berkembang menjadi isu nasional, bahkan tidak berbatas negara. Kegamangan akan terjadinya konflik destruktif menjadi hal yang bukan tidak mungkin terjadi.

Melihat pola yang ada sekarang, kesadaran masyarakat dalam era baru penjajahan globalisasi hampir tidak ada. Dapat diprediksi bahwa di tahun-tahun mendatang Indonesia tetap akan mempertahankan peringkat dunia atau bahkan naik peringkat sebagai bangsa konsumen di dunia, mulai dari penggunaan internet hingga jumlah pengguna jejaring sosial media. Jumlah penduduk yang banyak diiringi laju pertumbuhan penduduk tanpa diimbangi edukasi untuk bijak dalam memanfaatkan teknologi menjadi faktor pendukung. Upaya membangun kesadaran melalui pendidikan diajukan untuk melindungi dari potensi konflik destruktif yang mengakibatkan instabilitas bangsa.

Konsep kesadaran dari kesadaran diskursif, kesadaran praktis, dan motif-motif tidak sadar/kognisi dapat menjadi jalan keluar dari permasalahan kerentanan masyarakat 
digital multikultural di Indonesia (Giddens, Teori Strukturasi: Dasar-Dasar Pembentukan Struktur Sosial Masyarakat, 2010). Masyarakat tidak hanya dituntut keluar dari masyarakat konsumsi pasif menjadi masyarakat konsumsi potensial, namun juga dapat mengembangkan kesadaran dari kesadaran praktis dan motif-motif tidak sadar/kognisi menjadi kesadaran diskursif. Masyarakat diharapkan dapat mengembangkan monitoring reflektif terhadap tindakan agar dapat mengantisipasi konsekuensi dari tindakan yang tidak diketahui akan berdampak pada aspek yang lebih luas terhadap anggota masyarakat lain (Giddens, Teori Strukturasi: Dasar-Dasar Pembentukan Struktur Sosial Masyarakat, 2010). Tentu hal ini menjadi tanggung jawab bersama mengingat melindungi dari potensi konflik destruktif yang mengakibatkan instabilitas bangsa merupakan tujuan yang harus diutamakan.

\section{KESIMPULAN}

Indonesia sebagai negara berkembang dengan jumlah penduduk terbanyak di dunia serta didukung tingkat perekonomian yang mengalami kenaikan setiap tahunnya menjadi target pasar strategis industri telekomunikasi. Indonesia menduduki peringkat dunia sebagai masyarakat dengan tingkat konsumsi terbesar dalam penggunaan internet, ponsel, hingga

\section{DAFTAR PUSTAKA}

jejaring sosial media. Ini bukan semata tindakan masyarakat sebagai individu, namun terbingkai dalam dimensi globalisasi yang melibatkan hubungan antar negara dalam kerangka struktur sistem ekonomi kapitalis dunia. Kepentingan ekonomi menjadikan negara produsen mengkomodifikasi perbedaaan dalam konsep modern dan tradisional untuk kepentingan ekspansi pasar. Bentuk dan pola komunikasi bergeser menciptakan era masyarakat digital yang merupakan dampak dari dualitas masyarakat dan struktur ekonomi kapitalis melahirkan sikap penerimaan masyarakat dalam konsep masyarakat konsumsi pasif dan potensial. Perbedaan dalam pengertian luas dikomodifikasi ulang oleh masyarakat konsumsi potensial kepada msyarakat konsumsi pasif untuk mencapai kepentingan politik kekuasaan dan ekonomi berupa keuntungan finansial. Menjadi tanggung jawab bersama untuk mengembangkan kesadaran diskursif melalui

pendidikan multikulural dan penggunakan teknologi secara bijak dengan membangun kesadaran masyarakat dapat menjadi jalan keluar dari permasalahan kerentanan masyarakat digital multikultural di Indonesia. 
Nasution, R. D. (2017). Pengaruh Perkembangan Teknologi Informasi Komunikasi terhadap Eksistensi Budaya Lokal. Penelitian Komunikasi dan Opini Publik, 21 (01), 30-42.

Giddens, A. (2005). Konsekuensi-Konsekuensi Modernitas. Yogyakarta: Kreasi Wacana.

Giddens, A. (2010). Teori Strukturasi: Dasar-Dasar Pembentukan Struktur Sosial Masyarakat. Yogyakarta: Pustaka Pelajar.

Harahap, N. (2014). Penelitian Kepustakaan. Iqra', 08 No. 1, 68-73.

Elo, S., \& Kyngas, H. (2008). The Qualitative Content Analysis Process. Advanced Nursing , 62 (01), 107-115.

Perdana, J. (2017, March 9). Oppo di Indonesia, Awalnya Coba-Coba Sekarang Nagih. Retrieved October 29, 2017, from Marketeers: http://marketeers.com/oppo-indonesia-coba-cobanagih/

Bohang, F. K. (2016, December 18). Samsung Masih Rajai Pasar Smartphone Indonesia, Ditempel Oppo. Retrieved October 29, 2017, from Kompas: http://tekno.kompas.com/read/2016/12/18/08464977/samsung.masih.rajai.pasar.smartphone. indonesia.ditempel.oppo

Badan Pusat Statistik. (2016). Dalam Ringkasan Eksekutif Pengeluaran dan Konsumsi Penduduk Indonesia (hal. 43). Jakarta: Badan Pusat Statistik.

Faliyandra, F. (2017, September 11). Indonesia Ranking 5 Pengguna Internet di Dunia dan Antisipasi Dampaknya. Retrieved October 2017, 2017, from Kompasiana: https://www.kompasiana.com/faisalfaliyandra/59b69c0e08e6ba2c71698812/indonesiaranking-5-pengguna-internet-di-dunia-dan-antisipasi-dampaknya

Sukoco, M. (2017, February 9). Netizen Indonesia, Angka Literasi, dan Maraknya Hoax. Retrieved October 29, 2017, from Kompasiana: https://www.kompasiana.com/maniksukoco/netizenindonesia-angka-literasi-dan-maraknya-hoax_589bcaf18d7e61450ecd4cbc

Bohang, F. K. (2017, July 27). Indonesia, Pengguna Instagram Terbesar se-Asia Pasifik. Retrieved October 29, 2017, from Kompas: http://tekno.kompas.com/read/2017/07/27/11480087/indonesia-pengguna-instagramterbesar-se-asia-pasifik

Kuwado, F. J. (2017, 06 01). Ini Isi Pidato Jokowi pada Hari Lahir Pancasila yang Disebar ke Penjuru Indonesia. Dipetik 09 17, 2017, dari Kompas: http://nasional.kompas.com/read/2017/06/01/13572831/ini.isi.pidato.jokowi.pada.hari.lahir. pancasila.yang.disebar.ke.penjuru.indonesia

Yusuf, O. (2014, 11 24). Pengguna Internet Indonesia Nomor Enam Dunia. Dipetik 09 17, 2017, dari

Kompas:http://tekno.kompas.com/read/2014/11/24/07430087/Pengguna.Internet.Indonesia. Nomor.Enam.Dunia

Winarno, B. (2008). Globalisasi: Peluang atau Ancaman bagi Indonesia. Dalam B. Winarno, Globalisasi: Peluang atau Ancaman bagi Indonesia (hal. 63). Jakarta: Erlangga. 
Winarno, B. (2007). Sistem Politik Indonesia Era Reformasi. In B. Winarno, Sistem Politik Indonesia Era Reformasi (p. 14). Yogyakarta: Medpress.

Kuwado, F. J. (2017, 06 01). Ini Isi Pidato Jokowi pada Hari Lahir Pancasila yang Disebar ke Penjuru Indonesia. Dipetik 09 17, 2017, dari Kompas: http://nasional.kompas.com/read/2017/06/01/13572831/ini.isi.pidato.jokowi.pada.hari.lahir. pancasila.yang.disebar.ke.penjuru.indonesia 